\title{
Effects of Stormwater Management and an Extended Culvert on Stream Health in Dug Run, Allen County, Ohio, USA
}

\author{
DAVID A. ZUWERINK ${ }^{1}$ and JAMES PETTY, University of Northwestern Ohio, Lima, OH, USA; BETH SEIBERT, Allen Soil \\ and Water Conservation District, Lima, OH, USA.
}

\begin{abstract}
Changes in stream hydrology and habitat-associated with urbanization-have impacted diversity, abundance, and movement of both macroinvertebrates and fish. In 2008 the University of Northwestern Ohio began developing the western half of the campus, incorporating stormwater management practices. This provided an opportunity to examine 3 sections of the Dug Run stream that flows through campus: 1 section on the western half of campus that filters stormwater through the soil, and 2 sections on the eastern half of campus which are affected by both urbanization and a culvert that extends under a building and a road. Significant differences in macroinvertebrate Stream Quality Monitoring (SQM) index scores $(p<0.001)$, fish diversity $(p<0.010)$, and abundance of Orangethroat Darters (Etheostoma spectabile) $(p<0.001)$ were observed between the western and the 2 eastern sections of Dug Run. Lower SQM index scores and lower Orangethroat Darter abundances were found in the urbanized sections of the stream, while lower fish diversity numbers were found upstream of the culvert. The western portion of campus, designed to filter stormwater runoff through the soil, was the only section studied with sensitive macroinvertebrates, a higher SQM index score, and a greater abundance of Orangethroat Darters.
\end{abstract}

OHIO J SCI 120(2):61-69

\section{INTRODUCTION}

Dug Run, a tributary of the Ottawa River in Allen County in northwestern Ohio, flows east to west along the southern border of The University of Northwestern Ohio. The university has been building around Dug Run, but changes in stormwater management regulations - and a desire for more green space- - has resulted in visual differences along the stream. Over $80 \%$ of the surface on the east end of the campus is impervious due to roads, parking lots, and buildings, with stormwater directed to the stream. Additionally, an approximately 128 $\mathrm{m}$ long culvert influences stream flow. The west end of campus, by contrast, was designed to carry stormwater into a series of retention basins. Once in the basins, the stormwater would be filtered by soil before reaching the stream (Patrick J. Beam, Beam Designs, personal communication). This difference in landscape design has provided an opportunity to observe the impact each design is having on Dug Run.

Changes in the land surface during urbanization have altered the type and magnitude of runoff processes (Booth and Bledsoe 2009). These hydrological changes can have dramatic impacts on the organisms living in the streams due to changes

${ }^{1}$ Address correspondence to David A. Zuwerink, University of Northwestern Ohio, 1744 Hartzler Road, Lima, OH 45805, USA. Email: dzuwerink@unoh.edu in pool-riffle sequences, changes in in-stream velocity, and alterations to in-stream habitat (Paul and Meyer 2001). Urban areas have been found to increase levels of nitrates, conductivity, turbidity, and temperature-while decreasing oxygen levels - in streams: all of these factors can contribute to poorer macroinvertebrate assemblages (Shilla and Shilla 2011). Several studies have shown that increasing the area of impervious surfaces and urban stormwater drainage can have negative impacts on stream biota (Walsh et al. 2005; Wang et al. 2012; Walsh and Webb 2016). Urbanization negatively affects both the diversity and abundance of macroinvertebrates and fish (Wheeler et al. 2005). Darter species have been negatively affected by urbanization (Onorato et al. 2000; Stranko et al. 2010). Kemp and Spotila (1997) captured more Tessellated Darters (Etheostoma olmstedi) in nonurbanized sites in the Valley Creek watershed while sampling during 1993 to 1994. Sampling in the Valley Creek watershed in 2001 to 2002 found no Shield Darters (Percina peltata) and reductions in Tessellated Darters, likely from urbanization (Steffy and Kilham 2006). The Johnny Darter (Etheostoma nigrum), Greenside Darter (Etheostoma blennioides), and Orangethroat

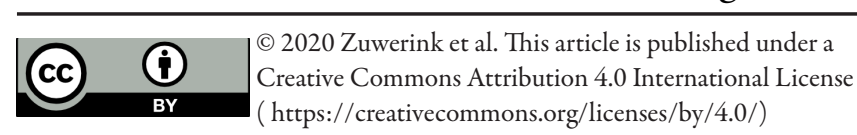


Darter (Etheostomaspectabile) have been captured in Dug Run (Ohio EPA 2013). While the Orangethroat Darter is more tolerant of turbid water and silted bottoms than other darter species, the Orangethroat Darter populations have been reduced in areas with heavy silting or where other pollutants become excessive (Trautman 1981).

Not only have changes in runoff negatively impacted stream health by increasing impervious surfaces along the stream, but the addition of culverts in urban areas change stream flow. Culverts tend to channelize streams, increase erosion and sedimentation, and influence water temperature (Vaughan 2002). These changes have negative impacts on stream biota (Khan and Colbo 2008; Favaro et al. 2014), the movement of fish (Benton et al. 2008), the number of fish, and alteration of stream habitat (Wheeler et al. 2005). Changes in stream flow, due to culverts, both impedes movement of indigenous species (Foster and Keller 2011) and lowers light levels that influence the movement of both fish and macroinvertebrates (Jones et al. 2017). Because the culvert in the current study-located on the east end of campus - is approximately $128 \mathrm{~m}$ in length and $2.5 \mathrm{~m}$ in width, it would affect stream flow, habitat, and light through a long stretch of the stream.

The goal of this project was to determine if macroinvertebrate and fish assemblages in Dug Run differed on 3 sections of the stream due to differences in stormwater management and the presence of an extended culvert. It was hypothesized that (1) Stream Quality Monitoring (SQM) index scores would be higher on the section managed for stormwater runoff, (2) fish diversity scores would differ between the 3 sections, (3) Orangethroat Darter abundance would differ between the 3 sections, and (4) SQM index scores would not change over the course of the study on the west end where stormwater is filtered by soil.

\section{METHODS AND MATERIALS}

The data for this study was collected in Dug Run from the fall of 2015 to the fall of 2018. Samples were collected 4 times a year during the months of September, January, April, and July. For this study, the stream was divided into 3 sections for analysis (Fig. 1). Section A is about $170 \mathrm{~m}$ long on the west end of campus. This area is surrounded by grass, athletic fields, and some buildings. In about one-third of this section, the stream was straightened and the banks were sloped back to reduce erosion. Upstream of this section is a narrow woodlot bordering both sides. This end of campus was designed so stormwater does not reach the stream as surface runoff, but rather is absorbed by the ground. Section B is $240 \mathrm{~m}$ long and is highly urbanized downstream of a culvert. Buildings and parking lots were built near the stream. Erosion control measures, including netting and rip rap, were installed near the footbridges crossing the stream. Pipes from the parking lots divert stormwater directly to the stream. Section $\mathrm{C}$ is $170 \mathrm{~m}$ long and is upstream of the culvert. There is a woodlot upstream of the primary section sampled. There are some dry retention basins to prevent stormwater from directly entering the stream, but some stormwater does run into the stream.

To sample macroinvertebrates a kick-seine was placed on the downstream end of the riffle, then one person would use their boots to stir up the streambed in the riffle upstream of the net. After the sediment settled out, the net was lifted, rolled up, and taken to a cloth sheet where it was unrolled. Nets were checked for organisms; for identification, organisms collected were placed in plastic trays filled with water. Once macroinvertebrates were collected and identified, the nets were lifted and the sheets were checked for organisms that moved through the net. Most species were individually counted, but the numbers of highly abundant species such as midge

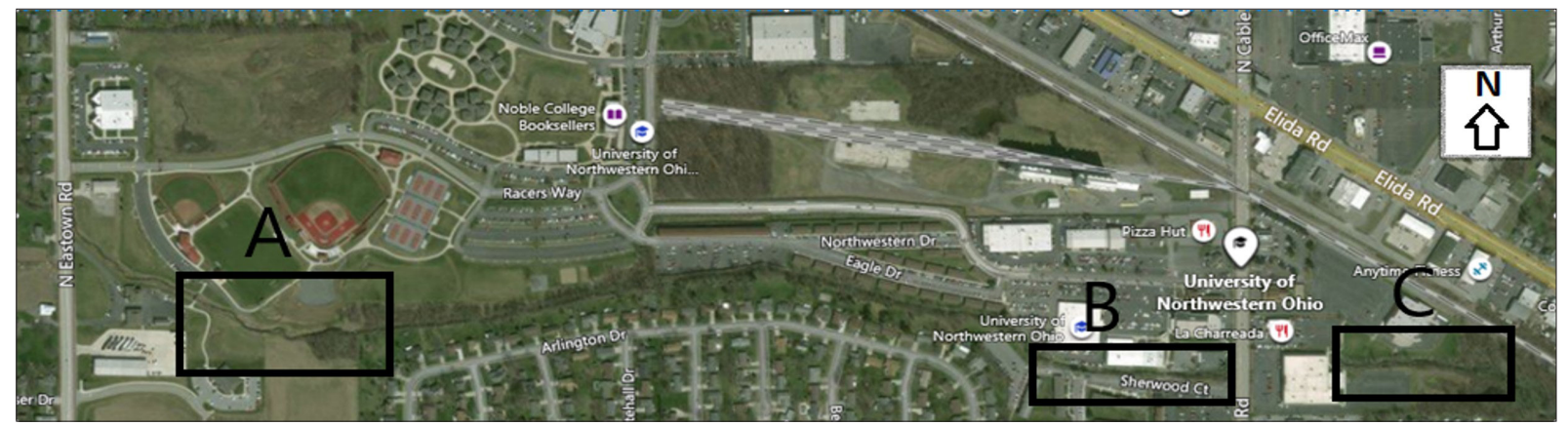

FIGURE 1. Graphic showing the 3 sections (A, B, and C) that were studied in Dug Run, at the University of Northwestern Ohio, from fall 2015 to fall 2018. A culvert (approximately $128 \mathrm{~m}$ long) extends from the eastern border of section B to the western border of section C. Dug Run flows through this culvert, below a building, parking lot, and road. 
larvae, aquatic worms, and planaria were estimated by counting the number found in a smaller area and multiplying that count based on total area. It was assumed that these estimates were consistent, but abundance was not used in the statistical analyses. Instead, macroinvertebrate SQM index scores were calculated using the Ohio EPA stream quality assessment form (Kopec and Lewis 1983).

Fish were collected in each section using a minnow seine, measuring $1.2 \mathrm{~m}$ high $\times 1.8 \mathrm{~m}$ wide with a $5 \mathrm{~mm}$ mesh, during 0.5 -hour blocks as part of a classroom project. Each 0.5-hour block was considered 1 sample. All fish collected during the sampling period were placed in a bucket. After the sampling period the fish were identified, counted, and released back into the same reach of the stream. Each class was given a different portion of the stream to sample to try to minimize impacts of disturbance and prevent collecting the same fish in subsequent samples. Fish diversity was calculated using the Shannon index (Shannon 1948).

Habitat was only evaluated in the spring of 2017. The qualitative habitat evaluation index (QHEI) was used to assess habitat quality (Rankin 1989), and the Wolman pebble count (Wolman 1954) was used to assess differences in riffle habitat between the 3 sections of the stream. The Kruskal-Wallis $\mathrm{H}$ test was used to analyze differences between the 3 sections of stream sampled. Spearman's $\rho$ was used to analyze any trend in the SQM index scores on the west end of campus over the course of the study.

\section{RESULTS}

A difference in the accumulated total value of macroinvertebrate assemblages was found-from the fall of 2015 to the fall of 2018-between the 3 locations, with a total of 17 groups of macroinvertebrates on the west end of campus (section A), 11 groups downstream of the culvert on the east end of campus (section B), and 9 groups upstream of the culvert on the east end of campus (section C) (Table). There were habitat differences between the 3 sites with substrate and riffle quality having the greatest influence on scores. A thin layer of silt was covering much of the sediment below the culvert.

Sensitive species were only found on the west end of campus (section A). There was a significant difference in macroinvertebrate SQM index scores between each of the 3 sections of the campus (Fig. 2) $(\mathrm{H}=23.01 ; p<0.001)$. A significant decline in SQM index scores was also observed over the course of the study on the west side of the campus $(\rho=-0.44 ; p=0.007)$, although the recent increase in SQM index scores suggests this trend may not be linear (Fig. 3). There was a significant difference in fish diversity between the 3 sections, although the difference was due to (1) lack of fish diversity upstream of the culvert (Fig. 4$)(\mathrm{H}=16.30$; $p<0.010$ ), and (2) a significant difference in Orangethroat Darter abundance between each section - with lower abundances in the urbanized sections (Fig. 5) $(\mathrm{H}=27.25 ; p<0.001)$.

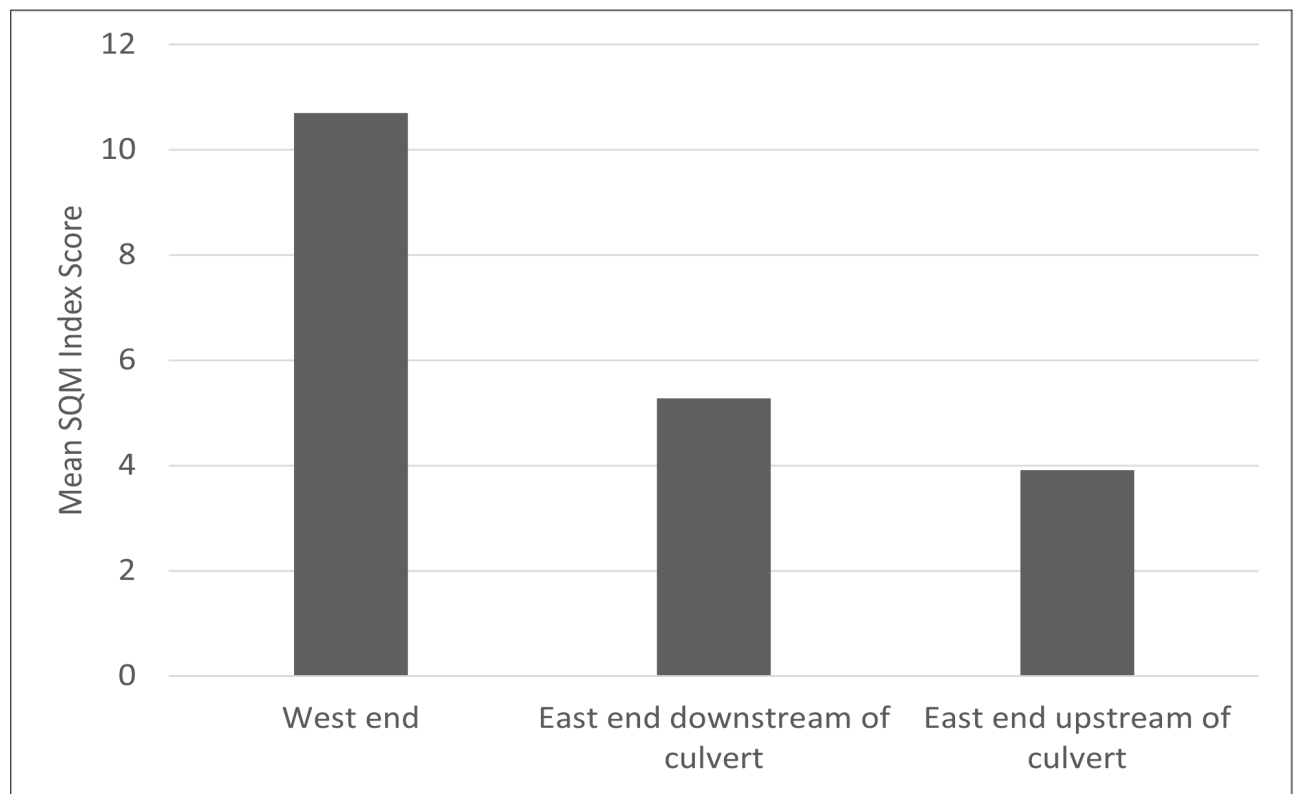

FIGURE 2. A comparison of Stream Quality Monitoring (SQM) index scores for macroinvertebrates at 3 sections of Dug Run on the University of Northwestern Ohio campus, fall 2015 to fall 2018. Samples were collected during the months of January, April, July, and September. 
Table

List of organisms and habitat characteristics collected in 3 sections of Dug Run, 2015 to 2018

\begin{tabular}{|c|c|c|c|}
\hline \multirow[b]{2}{*}{ Category } & \multicolumn{3}{|c|}{ Location } \\
\hline & $\begin{array}{l}\text { West } \\
\text { (section A) }\end{array}$ & $\begin{array}{l}\text { East } \\
\text { (downstream of } \\
\text { culvert - section B) }\end{array}$ & $\begin{array}{l}\text { East } \\
\text { (upstream of } \\
\text { culvert - section C) }\end{array}$ \\
\hline Habitat & \multicolumn{3}{|c|}{ Habitat evaluation } \\
\hline Qualitative habitat evaluation index & 58 & 58 & 41 \\
\hline \multicolumn{4}{|c|}{ Wolman pebble count } \\
\hline Pebble size range & $<0.06$ to $2,048 \mathrm{~mm}$ & 2 to $512 \mathrm{~mm}$ & $<0.06$ to $8 \mathrm{~mm}$ \\
\hline Primary size category & Coarse gravel & Coarse gravel & Very coarse sand \\
\hline Macroinvertebrates & \multicolumn{3}{|c|}{ Specimen capture per sample } \\
\hline Mayfly nymph (Ephemeroptera) ${ }^{a}$ & 3.36 & 0.00 & 0.00 \\
\hline Caddisfly larvae (Trichoptera) a & 4.58 & 0.00 & 0.00 \\
\hline Riffle beetle (Elmidae) ${ }^{a}$ & 0.17 & 0.00 & 0.00 \\
\hline Other snails (Prosobranchia) ${ }^{a}$ & 0.06 & 0.00 & 0.00 \\
\hline Damselfly nymph (Zygoptera) ${ }^{b}$ & 3.92 & 0.52 & 1.00 \\
\hline Dragonfly nymph (Anisoptera) ${ }^{b}$ & 0.06 & 0.36 & 0.18 \\
\hline Crane fly larvae (Tipulidae) ${ }^{\mathrm{b}}$ & 2.64 & 0.24 & 0.27 \\
\hline Beetle larvae (Berosus) ${ }^{\mathrm{b}}$ & 0.67 & 0.00 & 0.00 \\
\hline Crayfish (Decapoda) ${ }^{b}$ & 0.43 & 0.16 & 0.00 \\
\hline Scuds (Amphipoda) ${ }^{\mathrm{b}}$ & 2.08 & 8.20 & 3.27 \\
\hline Clams $(\text { Ferrissia })^{\mathrm{b}}$ & 2.78 & 0.00 & 0.00 \\
\hline Blackfly larvae (Simuliidae) ${ }^{c}$ & 1.33 & 0.68 & 0.27 \\
\hline Aquatic worms (Clitellata) ${ }^{c, d}$ & 76.17 & 61.36 & 77.09 \\
\hline Midge larvae (Diptera) ${ }^{c}$ & 193.89 & 63.08 & 61.64 \\
\hline Pouch snails (Archaeopulmonata) ${ }^{c}$ & 0.14 & 0.04 & 0.00 \\
\hline Leeches (Hirudinea) ${ }^{c}$ & 1.11 & 0.96 & 0.09 \\
\hline Planaria (Xenacoelomorpha) ${ }^{c}$ & 125.14 & 95.24 & 104.36 \\
\hline
\end{tabular}

${ }^{\text {a }}$ Sensitive to pollutants.

${ }^{\mathrm{b}}$ Somewhat sensitive to pollutants.

${ }^{\mathrm{c}}$ Very tolerant to pollutants.

${ }^{\mathrm{d}}$ Also reported as Oligochaeta. 
Table (continued)

List of organisms and habitat characteristics collected in 3 sections of Dug Run, 2015 to 2018

\begin{tabular}{|c|c|c|c|}
\hline \multirow[b]{2}{*}{ Category } & \multicolumn{3}{|c|}{ Location } \\
\hline & $\begin{array}{l}\text { West } \\
\text { (section A) }\end{array}$ & $\begin{array}{l}\text { East } \\
\text { (downstream of } \\
\text { culvert - section B) }\end{array}$ & $\begin{array}{l}\text { East } \\
\text { (upstream of } \\
\text { culvert - section C) }\end{array}$ \\
\hline Fish & \multicolumn{3}{|c|}{ Specimen capture per sample } \\
\hline Black Bullhead (Ameiurus melas) & 0.30 & 0.00 & 0.00 \\
\hline $\begin{array}{l}\text { Blackstripe Topminnow } \\
\text { (Fundulus notatus) }\end{array}$ & 2.56 & 0.38 & 0.09 \\
\hline Bluegill (Lepomis macrochirus) & 0.22 & 0.59 & 0.09 \\
\hline $\begin{array}{l}\text { Bluntnose Minnow } \\
\text { (Pimephales notatus) }\end{array}$ & 9.91 & 4.86 & 1.55 \\
\hline $\begin{array}{l}\text { Central Stoneroller } \\
\text { (Campostoma anomalum) }\end{array}$ & 2.88 & 5.90 & 6.36 \\
\hline $\begin{array}{l}\text { Creek Chub } \\
\text { (Semotilus atromaculatus) }\end{array}$ & 7.28 & 11.14 & 10.36 \\
\hline $\begin{array}{l}\text { Emerald Shiner } \\
\text { (Notropis atherinoides) }\end{array}$ & 0.06 & 0.00 & 0.00 \\
\hline $\begin{array}{l}\text { Gizzard Shad } \\
\text { (Dorosoma cepedianum) }\end{array}$ & 0.00 & 0.05 & 0.00 \\
\hline $\begin{array}{l}\text { Green Sunfish } \\
\text { (Lepomis cyanellus) }\end{array}$ & 0.16 & 1.05 & 0.09 \\
\hline $\begin{array}{l}\text { Largemouth Bass } \\
\text { (Micropterus salmoides) }\end{array}$ & 0.22 & 0.76 & 0.00 \\
\hline $\begin{array}{l}\text { Orangethroat Darter } \\
\text { (Etheostoma spectabile) }\end{array}$ & 6.50 & 2.10 & 0.91 \\
\hline $\begin{array}{l}\text { Redfin Shiner } \\
\text { (Lythrurus umbratilis) }\end{array}$ & 0.91 & 0.05 & 0.36 \\
\hline Sand Shiner (Notropis stramineus) & 0.06 & 0.14 & 0.00 \\
\hline $\begin{array}{l}\text { Silverjaw Minnow } \\
\text { (Notropis buccatus) }\end{array}$ & 1.22 & 0.33 & 0.55 \\
\hline $\begin{array}{l}\text { Spotfin Shiner } \\
\text { (Cyprinella spiloptera) }\end{array}$ & 7.53 & 4.00 & 5.45 \\
\hline $\begin{array}{l}\text { White Sucker } \\
\text { (Catostomus commersonii) }\end{array}$ & 3.50 & 3.29 & 6.18 \\
\hline
\end{tabular}




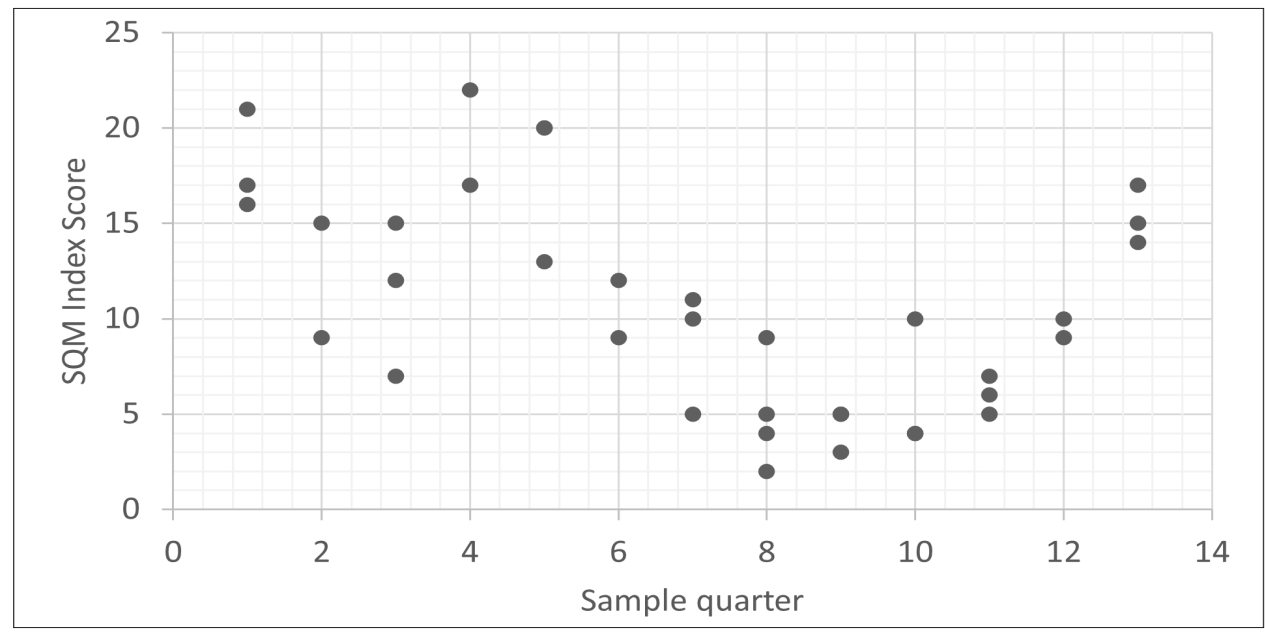

FIGURE 3. Changes in Stream Quality Monitoring (SQM) index scores of macroinvertebrates in Dug Run on the western end (section A) of the University of Northwestern Ohio campus, fall 2015 to fall 2018. Sample quarter 1 occurred in September 2015 with subsequent quarters occurring in the months of January, April, and July continuing to sample quarter 13 in September 2018.

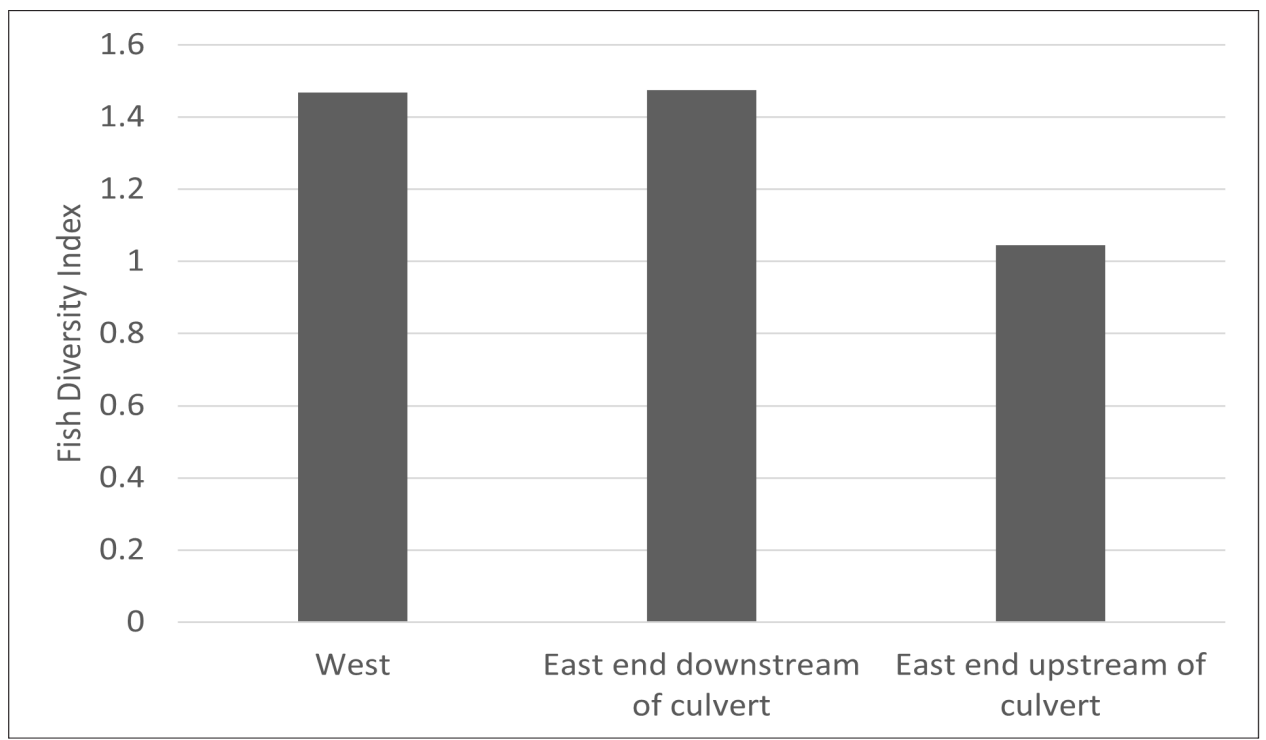

FIGURE 4. Comparison of fish diversity from 3 sections of Dug Run on the University of Northwestern Ohio campus, fall 2015 to fall 2018. Samples were collected during the months of January, April, July, and September.

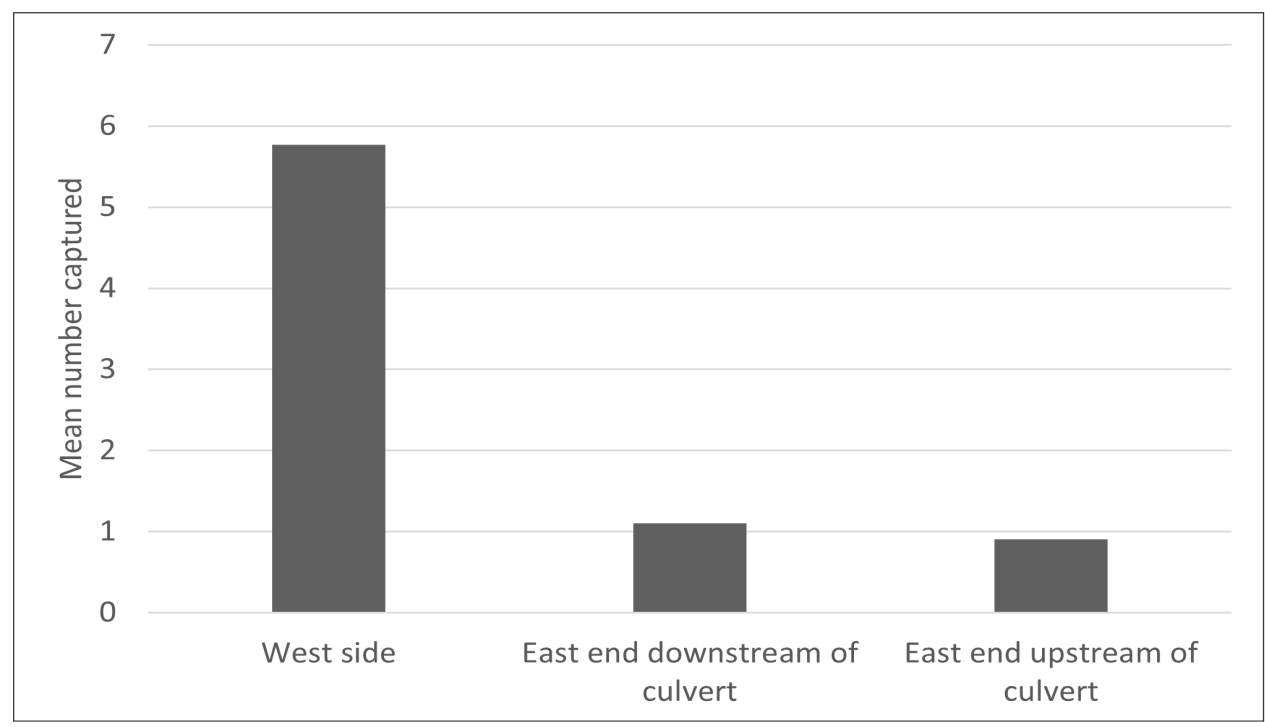

FIGURE 5. Comparison of Orangethroat Darter (E. spectabile) abundance on 3 sections of Dug Run on the University of Northwestern Ohio campus, fall 2015 to fall 2018. Samples were collected during the months of January, April, July, and September. 


\section{DISCUSSION}

The design of the west end of campus appears to have had a positive impact on the quality of the water in the stream. Although scores still remain low compared to natural areas, possibly due to channel modification throughout the study area, the presence of sensitive species on the west end is an indication of good water quality. Hydrological responses to urbanization have been found to contribute to lower Index of Biotic Integrity (IBI) scores (DeGasperi et al. 2009). Stahley and Kodani (2011) found lower macroinvertebrate scores near parking lots (possibly due to silt, oils, and automotive chemicals), while suburban areas also had depressed macroinvertebrate populations (possibly due to mowing or a lack of natural vegetation). Roy et al. (2014) found that stormwater management approaches that included biofiltration wales, pervious pavement, green roofs, and rain gardens did not translate into changes in biotic health. These results could be due to the length of their study, previous damage to the system, or outside stressors that were not impacted by managing stormwater runoff. This current study indicates that managing for stormwater runoff (on the west end of campus) resulted in the stream attaining higher SQM index scores than a section directly impacted by stormwater runoff (on the east end of campus). However, the lack of natural vegetation, combined with intensive mowing, may have contributed to lower scores than would be present in an undisturbed area of the stream.

Not only were differences observed in macroinvertebrates between the 3 sections of campus, but changes in SQM index scores also occurred over time on the western portion of the campus. Possible causes of decline in SQM index scores include removal of trees during the summer of 2016, natural cycles in insect populations, or disturbances due to quarterly sampling. Rios and Bailey (2006) found forest shade and coverage increased macroinvertebrate richness and diversity. Despite the presumption that aquatic insects do not have outbreaks, Lancaster and Downes (2018) found examples of cyclical patterns in aquatic insects. Increases in SQM index scores at the western portion of campus (section A), observed toward the end of the reporting period, may indicate that at least some of the decline may be due to cyclical patterns in yearly insect populations. Small changes in canopy cover and annual insect cycles could have stronger impacts on SQM index scores at sites without a large number of sensitive species.

Fish diversity did not appear to be affected in the section surrounded by buildings and parking lots; however, the presence of the culvert did appear to reduce diversity by affecting habitat upstream of the culvert. Sediment is being trapped above the culvert; below the culvert the water has scoured the stream down to the bedrock in some places. While research has shown that urbanization affects fish diversity (Tabit and Johnson 2002), the presence of several more tolerant species in the section of Dug Run that was studied, and/or passive sampling, likely contributed to the lack of differences that were found. Similar to the present study, Wellman et al. (2000) found that culverts caused sediment accumulationalthough they did not find this impacted fish diversity. The lack of fish diversity upstream of the culvert on the UNOH site could be due to the length of the culvert. The Orangethroat Darter (one of the more sensitive species found in the current study) was rare in the urbanized sections, suggesting this fish had been negatively affected by pollution from the paved surfaces. A large amount of silt can be seen in the stream, west of the culvert (section B), likely coming from the surrounding parking lots. Other studies have also found urbanization to negatively impact darter species (Tabit and Johnson 2002; Wheeler et al. 2005; Horwitz et al. 2008), and Orangethroat Darters have been negatively impacted in areas with excessive siltation and pollution (Trautman 1981). The Johnny Darter and Greenside Darter have been collected further downstream in Dug Run (OhioEPA 2013) but were not collected in the current study, possibly due to impacts related to urbanization.

\section{Conclusion}

This study provides evidence that stormwater management practices can have positive effects on macroinvertebrates and some fish, although mitigating stormwater alone is insufficient to maintain a highly diverse and healthy population. Booth (2005) suggested restorative land use planning actions required to attain a sustainable ecological goal: creating reserves, minimizing the footprint of road and utility crossings, preforming hydrologic rehabilitation such as stormwater infiltration or onsite retention and erosion control, re-establishing age structure of riparian vegetation, and reconnecting floodplains with their associated channels. 
Riparian vegetation influences macroinvertebrate assemblages (Rios and Bailey 2006), with natural riverbanks providing the most suitable habitat for macroinvertebrates as compared to rip rap, fascine, and other bank stabilization efforts (Cavaillé et al. 2018). Vegetation cover can influence temperatures and provide food for macroinvertebrates and fish, help stabilize banks, and reduce erosion that could damage habitat important to aquatic organisms. Maintaining as many natural stream characteristics as possible can help minimize damage to in-stream communities.

\section{ACKNOWLEDGEMENTS}

The authors wish to thank the students at the University of Northwestern Ohio who participated in collecting the data for this project. Jane Higbie, Rebecca Core, and Casey Heilman from the Allen Soil and Water Conservation District assisted students with data collection. Collection equipment was provided by the University of Northwestern Ohio and the Allen Soil and Water Conservation District.

\section{LITERATURE CITED}

Benton PD, Ensign WE, Freeman BJ. 2008. The effect of road crossings on fish movements in small Etowah Basin streams. Southeast Nat. 7(2):301-310.

https://doi.org/10.1656/1528-7092(2008)7[301:teorco]2.0.co;2

Booth DB, Bledsoe BP. 2009. Streams and urbanization. In: Baker LA, editor. The water environment of cities. Boston(MA): Springer. p. 93-123. ISBN13: 9780387848914

https://doi.org/10.1007/978-0-387-84891-4_6

Booth DB. 2005. Challenges and prospects for restoring urban streams: a perspective from the Pacific Northwest of North America. J N Am Benthol Soc. 24(3):724-737. https://doi.org/10.1899/04-025.1

Cavaillé P, Dumont B, Van Looy K, Floury M, Tabacchi E, Evette A. 2018. Influence of riverbank stabilization techniques on taxonomic and functional macrobenthic communities. Hydrobiologia. 807:19-35. https://doi.org/10.1007/s10750-017-3380-3

DeGasperi CL, Berge HB, Whiting KR, Burkey JJ, Cassin JL, Fuerstenberg RR. 2009. Linking hydrologic alteration to biological impairment in urbanizing streams of the Puget Lowland, Washington, USA. J Am Water Resour As. 45(2):512-533. https://doi.org/10.1111/j.1752-1688.2009.00306.x

Favaro C, Moore JW, Reynolds JD, Beakes MP. 2014. Potential loss and rehabilitation of stream longitudinal connectivity: fish populations in urban streams with culverts. Can J Fish Aquat Sci. 71(12):1805-1816.

https://doi.org/10.1139/cjfas-2014-0199
Foster HR, Keller TA. 2011. Flow in culverts as a potential mechanism of stream fragmentation for native and nonindigenous crayfish species. J N Am Benthol Soc. 30(4):1129-1137.

https://doi.org/10.1899/10-096.1

Horwitz RJ, Johnson TE, Overbeck PF, O’Donnell TK, Hession WC, Sweeney BW. 2008. Effects of riparian vegetation and watershed urbanization on fishes in streams of the Mid-Atlantic Piedmont (USA). J Am Water Resour As. 44(3):724-741. https://doi.org/10.1111/j.1752-1688.2008.00201.x

Jones MJ, Baumgartner LJ, Zampatti BP, Beyer K. 2017. Low light inhibits native fish movement through a vertical-slot fishway: implications for engineering design. Fisheries Manag Ecol. 24(3):177-185.

https://doi.org/10.1111/fme.12205

Kemp SJ, Spotila JR. 1997. Effects of urbanization on brown trout Salmo trutta, other fishes and macroinvertebrates in Valley Creek, Valley Forge, Pennsylvania. Am Midl Nat. 138(1):55-68.

https://doi.org/10.2307/2426654

Khan B, Colbo MH. 2008. The impact of physical disturbance on stream communities: lessons from road culverts. Hydrobiologia. 600:229-235.

https://doi.org/10.1007/s10750-007-9236-5

Kopec J, Lewis S. 1983. Stream quality monitoring. Columbus (OH): Ohio Department of Natural Resources, Division of Natural Areas and Preserves, Scenic Rivers Programs. $20 \mathrm{p}$

Lancaster J, Downes BJ. 2018. Aquatic versus terrestrial insects: real or presumed differences in population dynamics? Insects. 9(4):157.

https://doi.org/10.3390/insects9040157

Ohio EPA. 2013. Biological and water quality study of the Ottawa River and principal tributaries, 2010. Columbus $(\mathrm{OH})$ : State of Ohio Environmental Protection Agency, Division of Surface Water. 219 p. Ohio EPA Technical Report EAS/2012-12-13. Separate appendices are available. Available from:

https://epa.ohio.gov/dsw/document_index/psdindx

Onorato D, Angus RA, Marion KR. 2000. Historical changes in the ichthyofaunal assemblages of the upper Cahaba River in Alabama associated with extensive urban development in the watershed. J Freshwater Ecol. 15(1):47-63. https://doi.org/10.1080/02705060.2000.9663721

Paul MJ, Meyer JL. 2001. Streams in the urban landscape. Annu Rev Ecol Syst. 32(1):333-365.

https://doi.org/10.1146/annurev.ecolsys.32.081501.114040

Rankin ET. 1989. The Qualitative Habitat Evaluation Index [QHEI]: rationale, methods, and application. Columbus $(\mathrm{OH})$ : State of Ohio Environmental Protection Agency, Division of Water Quality Planning \& Assessment, Ecological Assessment Section. 73 p. https://www.epa.ohio.gov/Portals/35/documents/QHEI_1989.pdf

Rios SL, Bailey RC. 2006. Relationship between riparian vegetation and stream benthic communities at three spatial scales. Hydrobiologia. 553:153-160. https://doi.org/10.1007/s10750-005-0868-z 
Roy AH, Rhea LK, Mayer AL, Shuster WD, Beaulieu JJ, Hopton ME, Morrison MA, St Amand AL. 2014. How much is enough? Minimal responses of water quality and stream biota to partial retrofit stormwater management in a suburban neighborhood. PLoS ONE. 9(1):e85011. https://doi.org/10.1371/journal.pone.0085011

Shannon CE. 1948. A mathematical theory of communication. Bell Syst Tech J. 27(3):379-423. https://doi.org/10.1002/j.1538-7305.1948.tb01338.x

Shilla DJ, Shilla DA. 2011. The effect of catchment land use on water quality and macroinvertebrate assemblages in Otara Creek, New Zealand. Chem Ecol. 27(5):445-460. https://doi.org/10.1080/02757540.2011.575374

Stahley A, Kodani CH. 2011. Assessing small streams in the upper Ocmulgee watershed using the Georgia Adopt-aStream macroinvertebrate monitoring protocols. Georgia J Sci. 69(2):135-144. https://digitalcommons.gaacademy.org/gjs/vol69/iss2/6

Steffy LY, Kilham SS. 2006. Effects of urbanization and land use on fish communities in Valley Creek watershed, Chester County, Pennsylvania. Urban Ecosyst. 9:119-133. https://doi.org/10.1007/s11252-006-7901-5

Stranko SA, Gresens SE, Klauda RJ, Kilian JV, Ciccotto PJ, Ashton MJ, Becker AJ. 2010. Differential effects of urbanization and non-natives on imperiled stream species. Northeast Nat. 17(4):593-614. https://doi.org/10.1656/045.017.0406

Tabit CR, Johnson GM. 2002. Influence of urbanization on the distribution of fishes in a southeastern upper Piedmont drainage. Southeast Nat. 1(3):253-268. https://doi.org/10.1656/1528-7092(2002)001[0253:iouotd]2.0.co;2

Trautman MB. 1981. The fishes of Ohio. Columbus (OH): The Ohio State University Press. 782 p. ISBN13: 9780814202135
Vaughan DM. 2002. Potential impact of road-stream crossing (culverts) on the upstream passage of aquatic macroinvertebrates. United States Forest Service Report. 15 p. Report submitted to the United States Forest Service, San Dimas Technology and Development Center.

Walsh CJ, Roy AH, Feminella JW, Cottingham PD, Groffman PM, Morgan RP. 2005. The urban stream syndrome: current knowledge and the search for a cure. J N Am Benthol Soc. 24(3):706-723. https://doi.org/10.1899/04-028.1

Walsh CJ, Webb JA. 2016. Interactive effects of urban stormwater drainage, land clearance, and flow regime on stream macroinvertebrate assemblages across a large metropolitan region. Freshw Sci. 35(1):324-339. https://doi.org/10.1086/685105

Wang B, Liu D, Liu S, Zhang Y, Lu D, Wang L. 2012. Impacts of urbanization on stream habitats and macroinvertebrate communities in the tributaries of Qiangtang River, China. Hydrobiologia. 680:39-51. https://doi.org/10.1007/s10750-011-0899-6

Wellman JC, Combs DL, Cook SB. 2000. Long-term impacts of bridge and culvert construction or replacement on fish communities and sediment characteristics of streams. J Freshwater Ecol. 15(3):317-328. https://doi.org/10.1080/02705060.2000.9663750

Wheeler AP, Angermeier PL, Rosenberger AE. 2005. Impacts of new highways and subsequent landscape urbanization on stream habitat and biota. Rev Fish Sci. 13(3):141-164. https://doi.org/10.1080/10641260590964449

Wolman MG. 1954. A method of sampling coarse river-bed material. Eos Trans AGU. 35(6):951-956. https://doi.org/10.1029/tr035i006p00951 